\title{
Sleep Disturbance and Associated Factors among Adult People Living with HIV/AIDS at Dessie Referral Hospital Antiretroviral therapy clinic, Northeast, Ethiopia
}

\author{
Fatuma Degu \\ University of Gondar \\ Yeneabat Birhanu \\ University of Gondar \\ Abere Azagew ( $\nabla$ wabere@ymail.com ) \\ University of Gondar
}

Research article

Keywords: HIV/AIDS, Sleep Disturbance, Quality of Sleep

Posted Date: April 30th, 2020

DOI: https://doi.org/10.21203/rs.3.rs-24038/v1

License: (c) (1) This work is licensed under a Creative Commons Attribution 4.0 International License.

Read Full License 


\section{Abstract \\ Background}

Sleep disturbance is the leading health problem in the era of HIV/AIDS. The exact cause of sleep disturbance was not well known, but it is related to HIV itself, antiretroviral drugs side effect, and other HIV related disorders. This study aimed to assess the prevalence of sleep disturbance and associated factors among adult people living with HIV/AIDS.

\section{Methods}

A cross-sectional study was conducted. A total of 419 study participants participated in the study. A systematic random sampling method was employed. An interviewer-administered a method of data collection with a chart review was used. Pittsburg Sleep Quality of Index for assessing sleep disturbance was used. A binary logistic regression was conducted. The variables having a p-value $<0.05$ with $95 \% \mathrm{Cl}$ were used to declare an association.

\section{Results}

The prevalence of sleep disturbance was $36 \%$ (95\% Cl: $31-41 \%)$. The study revealed that being female (AOR $=3.45,95 \% \mathrm{Cl}: 1.52-7.79)$, viral loads $\geq 1000$ copies $/ \mathrm{ml}$ (AOR $=6.88,95 \% \mathrm{Cl}: 2.79-16.9), \mathrm{CD} 4$ cell count $<200$ cells $/ \mathrm{mm}^{3}$ (AOR $=6.85,95 \%$ Cl: $\left.2.42-19.39\right)$, WHO stage II and III(AOR $=4.29,95 \% \mathrm{Cl}: 1.05-$ 17.53), having anxiety $(A O R=10,95 \% \mathrm{Cl}: 4.21-23.9)$, having depression $(A O R=4.4,95 \% \mathrm{Cl}: 1.95-10.1)$, having not a separated bedroom ( $\mathrm{AOR}=3.94,95 \% \mathrm{Cl}$ : $1.86-8.36)$, and living alone $(\mathrm{AOR}=6,95 \% \mathrm{Cl}$ : $2.81-13.12$ ) were found to be factors associated with sleep disturbance.

\section{Conclusion}

In this study, more than one - thirds of the study participants were developed sleep disturbance. Being female, low CD4 cell counts, viral load $\geq 1000$ copies/ml, WHO stage II and III, having depression and anxiety, living alone, and have not a separate bedroom have increased the experience of sleep disturbance.

\section{Background}

Sleep disturbance is the leading health problem among people living with HIV/AIDS (PLWHA). It a symptom characterized by difficulty in initiating and maintaining sleep, excessive somnolence, disturbed sleep-wake schedule, and dysfunctions associated with sleep and sleep stage (1). The causes of sleep disturbance among PLWHA were still not well known, but some of the previous studies have suggested that HIV itself affects the central nervous system, lower immunity, antiretroviral medication side effects, 
and mental health issues largely affect the sleep quality (2-4). Low CD4 cell count, Efaverinz-based antiretroviral therapy (ART) regimen, duration of living with HIV/AIDS, stress, anxiety, and depression were risk of sleep disturbance (5-9).

Sleep disturbance leads to non-adherence to their recommend medications (10) which leads to a disease progression to a fatal stage (11). Decreased job performance, absent from work, more prone to accidents, decreased quality of life, increased health care cost, high rate of psychiatric co-morbidities (12), altered cognitive functioning (13), increase the risk developing hypertension, overweight (14), and increase unprotected sexual intercourse (15) were the major complications of sleep disturbance among PLWHA.

Simultaneous occurrence of sleep disturbance with HIV infection makes clinical management more complicated, so understanding the magnitude and major factors of sleep disturbance is playing a key role to identify and treat mental health problems early as much as possible. In Ethiopia, there is limited information on the prevalence and associated factors of sleep disturbance among adult PLWHA. Therefore, this study provides evidence on the prevalence and contributing factors for sleep disturbance. Besides, the results of the study provide baseline information for palliative care strategies to optimize and improve the quality of life by improving the service quality.

\section{Methods}

\section{Study Setting}

The study was conducted at the Dessie Referral Hospital adult ART clinic. The Dessie town is found in the Amhara regional province which is $451 \mathrm{Km}$ from Addis Abeba. The hospital started ART service since 1998 E.C. At the moment, there were around 5920 HIV positive patients enrolled in the ART clinic of which 5664 were adults. All adult PLWHA who were attending at ART clinic were considered as source population whereas those adult PLWHA attending the ART clinic during the data collection period were taken as the study population.

\section{Sample Size Determination}

The sample size was determined using a single population proportion formula considering the assumptions of a $95 \%$ confidence interval, $45.8 \%$ population proportion from the previous study (14), and $5 \%$ marginal error. Taking a $10 \%$ non-response rate, the final sample size was 419 . The sampling frame was developed based on the order of coming to the clinic. The sampling unit was determined and using systematic random sampling the study participants were selected every person pattern.

\section{Operational Definitions}

\section{Sleep disturbance}


Participants having a global score of Pittsburg Sleep Quality of Index (PSQI) $>5$ were considered as having sleep disturbance whereas having a global score of PSQI $\leq 5$ taken as having no sleeping disturbance (16).

\section{Stress}

On the perceived stress scale(PSS) a participant having a mean score of $0-13$ will be classified as low stress, $14-26$ moderate stress, and 27-40 sever stress (17).

\section{Depression}

Participants who had a mean score $>8$ considered as having depression were as a score of $8 \leq$ was considered as no depression. Participants who had a mean score $>8$ considering as having anxiety $\leq 8$ no anxiety from anxiety (18).

\section{Data Collection Tools And Procedures}

A structured interviewer-administered questionnaire with a chart review was employed to collect data. The questionnaire includes socio-demographic factors, clinically factors, personal and behavioral factors, and psychosocial factors. A validated PSQI tool was used. Its Crobanch alpha is $(0.88)(19,20)$. Sleep disturbance assessed with the 19 item questionnaires with 7-components including, subjective sleep quality, sleep latency, sleep duration, habitual sleep efficiency, sleep disturbances, use of sleeping medications, and daytime dysfunction during the last one month. Perceive stress scale (PSS) was used to assess the client's stress condition. It had 10 item stress scales ranging from $0-4$ points Likert scale with a score of minimum 0 and maximum 40 (17).

Anxiety was measured using the hospital anxiety scale. The tool had a 7 Likert scales ranging from $0-3$ with minimum 0 and maximum of 21 scores, which the higher score indicated had anxiety (18).

Depression was measured using the hospital depression scale. It had a 7 Likert scale ranging from $0-3$ points with score minimum 0 and maximum scores of 21 , the minimum score indicates no depression and the higher score indicates having depression (18). Four BSc nurses (three data collectors and one supervisor were used.

\section{Data Processing And Analysis}

Data were coded and entered into Epi Info Version 7 then exported to SPSS version 20 for analysis. Both descriptive and analytical statistical procedures were utilized. Descriptive statistics such as percentage, mean, median, standard deviation, and inter-quartile range (IQR) were used. Tables and bar graphs were also used for data presentation. A binary logistic regression model was used to identify factors associated with sleep disturbance. All explanatory variables enter into the multivariable logistic 
regression model to control the possible effect of confounders. The effect of variables on sleep disturbance was declared based on a $95 \% \mathrm{Cl}$ and $\mathrm{p}$-value $<0.05$. Model fitness was checked using Hosmer and Lemeshow goodness of a fit test.

\section{Results}

\section{Socio-demographic characteristics of the study participants}

A total of 419 participants were enrolled in the study, making a 100\% response rate. The median (IQR) age of participants was 36 (IQR 18-77) years. Nearly two-thirds (63.7\%) were females. Among study participants 180 (43\%) were married, 242 (57.8\%) were Muslim, 149 (35.6\%) were attended primary school, 357 (85.2\%) were urban dwellers, and 108 (25.8\%) were currently daily laborer. The median average family monthly income was 800 Ethiopian birr (IQR, 200-9000) (Table 1). 
Table 1

Socio-demographic characteristics of PLWHA at Dessie Referral Hospital ART clinic, Northeast Ethiopia, 2019 ( $n=$ 419).

\begin{tabular}{|lll|}
\hline Variables & Frequency(n) & Percent (\%) \\
\hline Sex & & \\
\hline Male & 152 & 36.3 \\
\hline Female & 267 & 63.7 \\
\hline Age group & & \\
\hline 18-35 years & 207 & 49.4 \\
\hline >35 years & 212 & 50.6 \\
\hline Marital status & & \\
\hline Single & 109 & 26 \\
\hline Married & 180 & 43 \\
\hline Divorce & 79 & 18.9 \\
\hline Widowed & 51 & 12.2 \\
\hline Religion & 64 & \\
\hline Orthodox & 108 & 14.5 \\
\hline Muslim & 172 & 41.1 \\
\hline Protestant & 242 & 57.8 \\
\hline Education & 5 & 1.20 \\
\hline Unable to read and write & 114 & \\
\hline Primary school & 149 & 27.2 \\
\hline Secondary school & 95.6 \\
\hline College and above & 61 & \\
\hline Residence & & \\
\hline Urban & & \\
\hline Rural & & \\
\hline Occupation & & \\
\hline Student & & \\
\hline Daily labour & & \\
\hline
\end{tabular}




\begin{tabular}{|lll|}
\hline Variables & Frequency(n) & Percent (\%) \\
\hline Farmer & 35 & 8.4 \\
\hline House wife & 85 & 20.3 \\
\hline Civil servant & 55 & 13.1 \\
\hline Merchant & 16 & 3.8 \\
\hline Monthly income & & \\
$\leq 1000$ birr & 266 & 63.5 \\
\hline$>1000$ birr & 153 & 36.5 \\
\hline
\end{tabular}

\section{Clinical Characteristic Of The Study Participants}

Among study participants, 266 (63.5\%) had > 5 years since first HIV diagnosis, 114 (27.2\%) were overweight, $393(93.8 \%)$ were WHO treatment stage I, $258(61.6 \%)$ had CD4 count $>350 \mathrm{cells} / \mathrm{mm}^{3}$, and $255(60.85 \%)$ had viral loads < 1000 copies / ml. Regarding ART status, $281(67.1 \%)$ were used efavirenzbased regimen and 266 (63.5\%) had good ART adherence. Nearly fifteen percent of study participants had co-morbidity and six percent of the participants' had history opportunistic infections (Table 2). 
Table 2

The clinical characteristics of PLWHA at Dessie Referral Hospital ART clinic, Northeast Ethiopia, $2019(n=419)$.

\begin{tabular}{|c|c|c|}
\hline Variables & Number (n) & Percent (\%) \\
\hline \multicolumn{3}{|l|}{ Duration HIV infection } \\
\hline$>5$ years & 266 & 63.5 \\
\hline$\leq 5$ years & 153 & 36.5 \\
\hline \multicolumn{3}{|l|}{ BMI } \\
\hline $18.5-25 \mathrm{~kg} / \mathrm{m}^{2}$ & 255 & 60.9 \\
\hline$<18 \mathrm{~kg} / \mathrm{m}^{2}$ & 50 & 11.9 \\
\hline$>25 \mathrm{~kg} / \mathrm{m}^{2}$ & 114 & 27.2 \\
\hline \multicolumn{3}{|l|}{ Current WHO staging } \\
\hline Stage I & 393 & 93.8 \\
\hline Stage II and above & 26 & 6.2 \\
\hline \multicolumn{3}{|l|}{ Recent CD4 cell count } \\
\hline$>350 \mathrm{cell} / \mathrm{mm}^{3}$ & 255 & 60.85 \\
\hline $200-350$ cell $/ \mathrm{mm}^{3}$ & 83 & 19.8 \\
\hline$<200$ cell $/ \mathrm{mm}^{3}$ & 81 & 19.33 \\
\hline \multicolumn{3}{|l|}{ Recent viral load } \\
\hline$<1000 \mathrm{copy} / \mathrm{ml}$ & 315 & 75.4 \\
\hline$\geq 1000 \mathrm{copy} / \mathrm{ml}$ & 104 & 24.6 \\
\hline \multicolumn{3}{|l|}{ Current ART regimen } \\
\hline Efavirez based ART regimen & 281 & 67.1 \\
\hline Nevirapine -based ART regimen & 100 & 23.9 \\
\hline Lobenavier / Atazenavier based ART & 38 & 9.1 \\
\hline \multicolumn{3}{|l|}{ ART adherence } \\
\hline Good & 279 & 66.6 \\
\hline Fair & 70 & 16.7 \\
\hline Poor & 70 & 16.7 \\
\hline
\end{tabular}




\begin{tabular}{|lll|}
\hline Variables & Number (n) & Percent (\%) \\
\hline History of co-morbidity & & \\
\hline Yes & 61 & 14.6 \\
\hline No & 358 & 85.4 \\
\hline Current opportunistic infection & & \\
Yes & 26 & 6.2 \\
\hline No & 393 & 93.8 \\
\hline
\end{tabular}

\section{Psychosocial and behavioral characteristics of the study participants}

Among study participants, 128 (30.5\%) had anxiety, 156 (37.2\%) had depression, and 49 (11.7\%) had severe stress. Regarding behavioral habits, 55 (13.1\%) were chewed khat once in their lifetime, 46 (11\%) were currently chewing khat, $30(7.2 \%)$ were currently drinking alcohol, and $16(3.8 \%)$ were currently smoking a cigarette (Table 3). 
Table 3

Psychosocial and behavioral characteristics of PLWHA at Dessie Referral Hospital, ART clinic Northeast Ethiopia, $2019(n=419)$.

\begin{tabular}{|lll|}
\hline Variables & Frequency(n) & Percent (\%) \\
\hline Anxiety & & \\
\hline Yes & 128 & 30.5 \\
\hline No & 291 & 69.5 \\
\hline Depression & & \\
\hline Yes & 156 & 37.2 \\
\hline No & 263 & 62.8 \\
\hline Stress & & \\
\hline Low & 73 & 8.8 \\
\hline Moderate & 333 & 79.5 \\
\hline Sever & 49 & 11.7 \\
\hline Khat chewed status & & \\
\hline Never chewed & 318 & 75.9 \\
\hline Former chewed & 55 & 13.1 \\
\hline Current chewed & 46 & 11 \\
\hline Alcohol drink status & & 9.2 \\
\hline Yes & 30 & 92.8 \\
\hline No & 389 & \\
\hline Smoking status & & \\
\hline Never Smoked & 381 & \\
\hline Former smoked & 22 & \\
\hline Current smoked & 16 & \\
\hline & & \\
\hline
\end{tabular}

\section{Prevalence Of Sleep Disturbances}

The prevalence of sleep disturbance among PLWHA was found to be $36 \%(95 \% \mathrm{Cl} ; 31 \%-41 \%)$ of which 118 (78.1\%) females. The median PSQI score was 3 (IQR: 0-17). 


\section{Characteristics Of Sleep Pattern Of The Study Participants}

The participants went to bed on average 10:02 pm and wake up in the morning at 4:08 am. The mean time slept each night was 7:02 hrs (SD \pm 1.07 hours). Two hundred twenty one $(52.7 \%)$ had very good sleep quality, $120(28.6 \%)$ had slept with $>60$ minutes and $86(20.5 \%)$ slept $<5: 00$ per 24:00 hours (Table 4). 
Table 4

Characteristics of Sleep among PLWHA at Dessie Referral Hospital, ART clinic $2019(n=419)$.

\begin{tabular}{|c|c|c|}
\hline Variables & Frequency (n) & Percent (\%) \\
\hline \multicolumn{3}{|l|}{ sleep Quality } \\
\hline Very good & 221 & 52.7 \\
\hline Fairly good & 80 & 19.1 \\
\hline Fairly bad & 40 & 9.5 \\
\hline Very bad & 78 & 18.6 \\
\hline \multicolumn{3}{|l|}{ Sleep latency } \\
\hline$<15$ mints not during the past month & 170 & 40.6 \\
\hline $16-30$ mints once or twice a week & 78 & 18.6 \\
\hline $31-60$ min once or twice a week & 51 & 12.2 \\
\hline > 60 mints 3times a week & 120 & 28.6 \\
\hline \multicolumn{3}{|l|}{ Sleep duration } \\
\hline$>7 \mathrm{hrs}$ & 251 & 59.9 \\
\hline $6-7 \mathrm{hrs}$ & 47 & 11.2 \\
\hline $5-6 \mathrm{hrs}$ & 35 & 8.4 \\
\hline$<5 \mathrm{hrs}$ & 86 & 20.5 \\
\hline \multicolumn{3}{|l|}{ Habitual sleep } \\
\hline \multicolumn{3}{|l|}{ Efficacy } \\
\hline$\geq 85 \%$ & 319 & 76.1 \\
\hline $75 \%-84 \%$ & 17 & 4.1 \\
\hline $65 \%-74 \%$ & 30 & 7.2 \\
\hline$<65 \%$ & 53 & 12.6 \\
\hline \multicolumn{3}{|l|}{ Sleep disturbance } \\
\hline none & 193 & 46.1 \\
\hline mild (1-9) & 207 & 49.4 \\
\hline moderate (10-18) & 3 & 0.7 \\
\hline Sever (19-27) & 16 & 3.8 \\
\hline
\end{tabular}




\begin{tabular}{|lll|}
\hline Variables & Frequency (n) & Percent (\%) \\
\hline Used sleep medication & & \\
\hline Not during the last month & 390 & 93.1 \\
\hline less than once a week & 12 & 2.9 \\
\hline once or twice a week & 6 & 1.4 \\
\hline$\geq 3$ times a week & 11 & 2.6 \\
\hline Daytime dysfunction & & \\
\hline No problem & 280 & 66.8 \\
\hline Slight problem(1-2/week & 109 & 26 \\
\hline Moderate problem > 2/week) & 21 & 5 \\
\hline Big problem $>$ 3/week & 9 & 2.1 \\
\hline
\end{tabular}

\section{Reasons For Difficulty In Maintaining Sleep}

The above half (56.6\%) of PLWHA were facing the difficulty in maintaining sleep due to unable to fall within 30 minutes (Fig. 1).

\section{Factors Associated With Sleep Disturbance}

All variables were computed in bivariable and multivariable logistic regression analysis to test the presence of an association. In multivariable analysis; being female ( $\mathrm{AOR}=3.45,95 \% \mathrm{Cl} ; 1.52-7.79$ ), viral loads $\geq 1000$ copies $(A O R=6.88,95 \% \mathrm{Cl} ; 2.79-16.9), \mathrm{CD} 4$ cell $<200$ cells $/ \mathrm{mm}^{3}(\mathrm{AOR}=6.85,95 \% \mathrm{Cl}$; 2.42-19.39), WHO stage II and III (AOR $=4.29,95 \% \mathrm{Cl}$; $1.05-17.53)$, having anxiety (AOR $=10,95 \% \mathrm{Cl}$; 4.21-23.9), having depression ( $A O R=4.44,95 \% \mathrm{Cl} ; 1.95-10.10)$, having separate bedroom $(A O R=3.94$, $95 \% \mathrm{Cl} ; 1.86-8.36)$, and living alone $(\mathrm{AOR}=6,95 \% \mathrm{Cl} ; 2.81-13.12)$ were determinant factors of sleep disturbance in PLWHA (Table 5). 
Table 5

Factors found significant multivariate analysis among PLWHA at Dessie Referral Hospital ART clinic, $2019(n=419)$.

\begin{tabular}{|c|c|c|c|c|}
\hline \multirow[t]{2}{*}{ Variable } & \multicolumn{2}{|c|}{ Sleep disturbance } & \multirow[t]{2}{*}{$\operatorname{COR}(95 \% \mathrm{Cl})$} & \multirow[t]{2}{*}{$\operatorname{AOR}(95 \%, \mathrm{Cl})$} \\
\hline & Yes & No & & \\
\hline \multicolumn{5}{|l|}{ Sex } \\
\hline Female & 121 & 146 & $3.37(2.114,5.373)$ & $3.45(1.52-7.79)^{\star}$ \\
\hline Male & 30 & 122 & 1 & 1 \\
\hline \multicolumn{5}{|c|}{ Taking coffee and tea } \\
\hline No & 69 & 137 & 1 & \\
\hline Yes & 82 & 131 & $1.24(0.83-1.85)$ & \\
\hline \multicolumn{5}{|l|}{ Smoking status } \\
\hline Never smoked & 126 & 255 & 1 & \\
\hline Current smoker & 11 & 5 & $4.4(1.5-13)$ & \\
\hline Past smoker & 14 & 8 & $3.5(1.4-8.7)$ & \\
\hline \multicolumn{5}{|l|}{ Khat chewing } \\
\hline Never chewed & 95 & 223 & 1 & \\
\hline Past chewed & 27 & 28 & $2.26(1.27-4)$ & \\
\hline \multicolumn{5}{|l|}{ Drinking alcohol } \\
\hline no & 136 & 253 & 1 & \\
\hline Yes & 15 & 15 & $1.86(.88-3.92)$ & \\
\hline \multicolumn{5}{|l|}{ Viral loads } \\
\hline < 1000 copies $/ \mathrm{ml}$ & 77 & 236 & 1 & 1 \\
\hline$\geq 1000$ copies $/ m l$ & 74 & 28 & $8.1(4.88-13.42)$ & $6.88(2.79-16.9)^{\star \star}$ \\
\hline
\end{tabular}


Table 5

Continued; Factors found significant multivariate analysis among PLWHA at Dessie Referral Hospital ART clinic, $2019(\mathrm{n}=419)$.

\begin{tabular}{|c|c|c|c|c|}
\hline \multirow[t]{2}{*}{ Variables } & \multicolumn{2}{|c|}{ Sleep disturbance } & \multirow[t]{2}{*}{ COR $(95 \% \mathrm{Cl})$} & \multirow[t]{2}{*}{ AOR $(95 \%, \mathrm{Cl})$} \\
\hline & Yes & No & & \\
\hline \multicolumn{5}{|l|}{ CD4 cells } \\
\hline > 350 cells $/ \mathrm{m} 3$ & 66 & 192 & 1 & 1 \\
\hline $200-350$ cells $/ \mathrm{mm} 3$ & 29 & 51 & $1.7(1-2.8)$ & \\
\hline$<200$ cells $/ \mathrm{mm} 3$ & 56 & 25 & $6.5(3.8-11)$ & $6.85(2.422-19.39)$ ** \\
\hline \multicolumn{5}{|l|}{ WHO stage } \\
\hline Stage I & 138 & 255 & 1 & 1 \\
\hline Stage II\& above & 13 & 13 & $1.84(.833-4.09)$ & $4.29(1.05-17.53)^{\star}$ \\
\hline \multicolumn{5}{|l|}{ Depression } \\
\hline No & 32 & 231 & 1 & 1 \\
\hline Yes & 119 & 37 & $23(13.8-39)$ & $4.44(1.95-10.1)^{\star \star}$ \\
\hline \multicolumn{5}{|l|}{ Anxiety } \\
\hline No & 42 & 249 & 1 & 1 \\
\hline Yes & 109 & 19 & $34(18.9-61)$ & $10(4.212-23.93)^{\star \star}$ \\
\hline \multicolumn{5}{|l|}{ Separate bedroom } \\
\hline Yes & 35 & 185 & 1 & 1 \\
\hline No & 116 & 83 & $7.4(4.7-11.7)$ & $3.94(1.86-8.36)^{\star \star}$ \\
\hline \multicolumn{5}{|l|}{ Live alone } \\
\hline No & 38 & 224 & 1 & 1 \\
\hline Yes & 113 & 44 & $15.14(9-24.7)$ & $6(2.81-13.12)^{\star \star}$ \\
\hline
\end{tabular}

\section{Discussion}

The current study showed that the prevalence of sleep disturbance among adult PLWHA was found to be $36 \%$ (95\% Cl: $31-41 \%)$. The prevalence was higher among females 118 (78.1\%). The finding of this study is in line with a study conducted in) and the USA, $40.93 \%(7)$ and China, $32.1 \%(9)$. It was lower than the 
study conducted in Nigeria 45.8\% (14), Cameroun 66.7\% (21), China 43.1\% (8), Iran 47.5\% (22), German $63 \%$ (23), Paris 68\% (16) and 63\% (24). The discrepancy was in socio-cultural characteristics, sampling methods, study setting, design, type of tool, and data collection methods. On the contrary, the finding of this study was higher than the study conducted in South Africa 16\% (25). The possible reason for this discrepancy may be due to the former study used longitudinal follow up which may lead to loss to follow.

The current study revealed that sex was the determinant factor of sleep disturbance. Being female was 3.45 times more likely to develop sleep disturbance compared to their counterparts ( $\mathrm{AOR}=3.45,95 \% \mathrm{Cl}$; 1.52 - 7.79). In females, during the premenopausal/menopausal period, there was a hormonal imbalance of estrogen and progesterone that decreased the level of estrogen as well progesterone level which results in a two-fold increase in the number of arousals after sleep occurs this decreased total sleep time (26).

Participants having viral loads greater or equal to 1000copies / $\mathrm{ml}$ were nearly 7 times more likely to develop sleep disturbance compared to those clients having viral loads less than 1000 copies $/ \mathrm{ml}$ (AOR = $6.88,95 \% \mathrm{Cl} ; 2.79-16.9)$. This is supported by a study conducted in California (10). High viral loads in the peripheral circulation enhance the HIV to enter into the central nervous system which activates macrophages and astrocytes (27) and consequently impaired their function which decreased the release of sleep regulatory substances(TNF-alpha) (28). Viral load increments associated with the disease progression to the chronic stage which changes sleep as more arousal and waking during sleep periods (29).

The odds of experiencing sleep disturbance among adult PLWHA who were WHO stage II\&III was 4.29 times compared to those WHO stage I ( $\mathrm{AOR}=4.29,95 \% \mathrm{Cl} ; 1.05-17.53)$. This is supported by a study conducted in UAS (30). Having advanced WHO clinical stage may lead to developing opportunistic infections that impair sleep quality.

Participants having a CD4 cells counts less than 200 cells $/ \mathrm{mm}^{3}$ were nearly 7 times more likely to develop sleep disturbance compared to those having CD4 cells count greater than $350 \mathrm{cell} / \mathrm{mm} \mathrm{m}^{3}$ (AOR = $6.85,95 \% \mathrm{Cl} ; 2.42-19.39$ ). This is supported by a study conducted in Nigeria (5) and the USA (31). Immune decrements associated with HIV infection is directly linked to the psyche by a complex network of nerves, hormones, and neuropeptides. This network has a direct impact on sleep (14). It has been well documented that CD 4 + cell count decreases, whereas viral load increases with the progression of HIV, consequently the quality of sleep worsens along the course of the disease, this related to CD $4+$ cell count and viral load as well (32).

Participants who had depression were 4.44 times more likely to develop sleep disturbance compared to those have no depression ( $\mathrm{AOR}=4.44,95 \% \mathrm{Cl} ; 1.95-10.10)$. This is supported by a study conducted in German (23) and five cities in the USA (7). Depression had a directional association between sleep disturbances (8). The reason is that in depression, the sleep-dependent component of sleep regulation is 
deficient and does not rise to its usual level. Due to this, the sleep amount of slow-wave sleep is reduced and the sleep period also shortened (33).

In the current study, participants who had anxiety were 10 times more likely to develop sleep disturbance compared to those participants with no anxiety $(A O R=10,95 \% \mathrm{Cl} ; 4.21-23.9)$. This is supported by a study conducted in China (8) and the USA (34). The reason is that, according to the polysomnographic features that characterize patients with anxiety have longer sleep onset latency, a greater number of arousals, and greater wake time during the night, fewer transitions into non-REM sleep (35).

In the present study, participants who lived alone had 6 times more likely to developed sleep disturbance compared to those living with their family $(A O R=6,95 \% \mathrm{Cl} ; 2.81-13.12)$. This is supported by a study conducted in the USA (36). Physical and social aspects of sleeping arrangements have been negatively affected the sleep quality (32). Better family and social support were associated with better sleep quality. Living with a supportive family can have a positive effect on mood, preventing social isolation, and promoting healthy sleep habits. Moreover, social support may help maintain a more consistent and consolidated sleep-wake schedule and may affect sleep by attenuating the effects of psychological stress on sleep $(6,37)$.

In the is study, participants who did not live in the separate bedrooms were nearly 4 times more like to develop sleep disturbance compared to those who lived in the separate bedrooms ( $\mathrm{AOR}=3.94,95 \% \mathrm{Cl}$; 1.86-8.36). This is supported by a study conducted in the USA (36). Sleep can be disrupted by a variety of factors related to the location of the bedroom in the house. Lack of separate bedrooms for sleep was predisposed to extra sound and light, sense of lack of security, expose for bright room colures, image or art, lack of privacy were negatively influence on the sleep quality (38).

\section{Limitation}

Variables such as sleep with partner and family size may affect sleep quality but this issue did not incorporate in the current study. Substances (Alcohol, cigarette, and khat) uses were not measured quantitatively.

\section{Conclusion}

The finding of this study showed that more than one-third of the study participants had sleep disturbance at the Dessie Referral Hospital ART clinic. Being female, low CD4 cell counts, viral loads $\geq 1000$ copies/ml, WHO stage (II and III), depression, anxiety, living alone, and having no separate bedrooms are factors associated with sleep disturbance.

\section{List Of Abbreviations}

ART; Antiretroviral Therapy, BMl; Body Mass Index, E.C; Ethiopian Calendar, HADS; Hospital AnxietyDepression Scale, PLWHA; People Living with HIV/AIDS, PSQl; Pittsburg Sleep Quality Index, WHO; World 


\section{Declarations}

\section{Ethical approval and consent to participate}

The study was approved by the Research Ethical Review Committee of the School of Nursing, College Medicine and Health Sciences on the behalf of the University of Gondar Research Ethical Review Board with the ref no. S/N/ 1600/06/2011 and approved on the date of 25/06/2011E.C. A formal letter indicating the approval obtained and submitted to Dessie Referral Hospital administrative. Written informed consent was obtained from each participant and personal identification like the name, phone number, and medical registration numbers were not used to maintain confidentiality.

\section{Consent for publication}

Not applicable

\section{Availability of data and materials}

The datasets used and/or analyzed during the current study are available at the corresponding author for reasonable request.

\section{Competing interests}

The authors declare that there is no competing of interests

\section{Funding}

The author did not receive any fund

\section{Authors' contribution}

FSD wrote the proposal, participated in data collection, analyzed the data, and drafted the manuscript. YB and AWA approved the proposal with revisions, participated in data collection, data analysis and revised subsequent drafts of the manuscript. All the authors read and approved the final manuscript.

\section{Acknowledgments}

The authors would like to express our gratitude to the University of Gondar College of Medicine and Health Sciences Research and Ethical Review Committee for the approval of the ethical clearance. The authors would like to thank data collectors and supervisors for their commitment and the study participants for their valuable information.

\section{References}


1. Schwartz WJ, Stakes JW, Martin JB. The sleep-wake cycle and disorders of sleep. Harrison's Principles of Internal Medicine New York, NY: McGraw-Hill International Book Co. 1987;111.

2. Omonuwa TS, Goforth HW, Preud, Rsquo X, Krystal AD. The pharmacologic management of insomnia in patients with HIV. J Clin SleepMed. 2009;5(03):251-62.

3. Vosvick M, Gore-Felton C, Ashton E, Koopman C, Fluery T, Israelski D, et al. Sleep disturbances among HIV-positive adults: The role of pain, stress, and social support. J Psychosom Res. 2004;57(5):45963.

4. Allavena C, Guimard T, Billaud E, De la Tullaye S, Reliquet V, Pineau S, et al. Prevalence and risk factors of sleep disturbance in a large HIV-infected adult population. AIDSBehav. 2016;20(2):339-44.

5. Oshinaike O, Akinbami A, Ojelabi O, Dada A, Dosunmu A, John Olabode S. Quality of sleep in an HIV population on antiretroviral therapy at an urban tertiary centre in Lagos, Nigeria. Neurol Res Int. 2014;2014.

6. Ren J, Zhao M, Liu B, Wu Q, Hao Y, Jiao M, et al. Factors associated with sleep quality in HIV. J Assoc NursesAIDS Care. 2018;29(6):924-31.

7. Sandoval R, Roddey T, Giordano TP, Mitchell K, Kelley C. Pain, sleep disturbances, and functional limitations in people living with HIV/AIDS-associated distal sensory peripheral neuropathy. J Int Assoc Provid AIDSCare. 2014;13(4):328-34.

8. Huang X, Li H, Meyers K, Xia W, Meng Z, Li C, et al. Burden of sleep disturbances and associated risk factors: A cross-sectional survey among HIV-infected persons on antiretroviral therapy across China. Sci Rep. 2017;7(1):3657.

9. Womack JA, Murphy TE, Bathulapalli H, Akgün KM, Gibert C, Kunisaki KM, et al. Sleep disturbance among HIV infected and uninfected Veterans. J Acquir ImmuneDefic Syndr (1999). 2017;74(4):e117.

10. Saberi P, Neilands TB, Johnson MO. Quality of sleep: associations with antiretroviral nonadherence. AIDSPatient Care STDS. 2011;25(9):517-24.

11. Phillips KD, Moneyham L, Murdaugh C, Boyd MR, Tavakoli A, Jackson K, et al. Sleep disturbance and depression as barriers to adherence. Clin Nurs Res. 2005;14(3):273-93.

12. Roth T. Insomnia: definition, prevalence, etiology, and consequences. J Clin SleepMed: Official Publication of the American Academy of Sleep Medicine. 2007;3(5 Suppl):S7.

13. Fortier-Brochu É, Beaulieu-Bonneau S, Ivers H, Morin CM. Insomnia and daytime cognitive performance: a meta-analysis. SleepMed Rev. 2012;16(1):83-94.

14. Shittu RO, Odeigah LO, Moradeyo AK, Sanni MA, Aderibigbe S, Sule AG, et al. Short Sleep Duration and Correlates among Sero-positive HIV Patients in Nigeria, West Africa. Br J Med Med Res. 2015;10(7):1-10.

15. Wakeham K, Harding R, Levin J, Parkes-Ratanshi R, Kamali A, Lalloo DG. The impact of antiretroviral therapy on symptom burden among HIV outpatients with low CD4 count in rural Uganda: nested longitudinal cohort study. BMCPalliat Care. 2018;17(1):8. 
16. Faraut B, Malmartel A, Ghosn J, Duracinsky M, Leger D, Grabar S, et al. Sleep disturbance and Total sleep time in persons living with HIV: a cross-sectional study. AIDSBehav. 2018;22(9):2877-87.

17. Cohen S, Kamarck T, Mermelstein R. Perceived stress scale. Measuring stress: a guide for health and social scientists. 1994. New York: Oxf Univ Press.

18. White D, Leach C, Sims R, Atkinson M, Cottrell D. Validation of the Hospital Anxiety and Depression Scale for use with adolescents. Br J Psychiatry. 1999;175(5):452-4.

19. Zeitlhofer J, Schmeiser-Rieder A, Tribl G, Rosenberger A, Bolitschek J, Kapfhammer G, et al. Sleep and quality of life in the Austrian population. ActaNeurol Scand. 2000;102(4):249-57.

20. Berhanu H, Mossie A, Tadesse S, Geleta D. Prevalence and associated factors of sleep quality among adults in Jimma town, Southwest Ethiopia: a community-based cross-sectional study. SleepDisord. 2018;2018.

21. Njamnshi A, Njoh A, Mbong E, Nfor L, Ngarka L, Fonsah J, et al. Sleep disorders in HIV-/INS; AIDS patients in Cameroon, Sub-Saharan Africa. Journal of the Neurological Sciences. 2013;333:e710.

22. Dabaghzadeh F, Khalili H, Ghaeli P, Alimadadi A. Sleep quality and its correlates in HIV positive patients who are candidates for initiation of antiretroviral therapy. Iran J Psychiatry. 2013;8(4):160.

23. Wibbeler T, Reichelt D, Husstedt I-W, Evers S. Sleepiness and sleep quality in patients with HIV infection. J Psychosom Res. 2012;72(6):439-42.

24. Byun E, Gay CL, Lee KA. Sleep, fatigue, and problems with cognitive function in adults living with HIV. J Assoc NursesAIDS Care. 2016;27(1):5-16.

25. Gómez-Olivé FX, Rohr JK, Roden LC, Rae DE, Von Schantz M. Associations between sleep parameters, non-communicable diseases, HIV status and medications in older, rural South Africans. Sci Rep. 2018;8(1):17321.

26. Yazdi Z, Sadeghniiat-Haghighi K, Ziaee A, Elmizadeh K, Ziaeeha M. Influence of sleep disturbances on quality of life of Iranian menopausal women. PsychiatryJ. 2013;2013.

27. McArthur JC, Brew BJ, Nath A. Neurological complications of HIV infection. LancetNeurol. 2005;4(9):543-55.

28. Zielinski MR, Krueger JM. Sleep and innate immunity. Front Biosci (Scholar edition). 2011;3:632.

29. Darko DF, Mitler MM, Henriksen SJ. Lentiviral infection, immune response peptides and sleep. Adv Neuroimmunol. 1995;5(1):57-77.

30. Phillips KD, Sowell RL, Boyd M, Dudgeon WD, Hand GA, Group MBR. Sleep quality and health-related quality of life in HIV-infected African-American women of childbearing age. Qual LifeRes. 2005;14(4):959-70.

31. Seay JS, Mclntosh R, Fekete EM, Fletcher MA, Kumar M, Schneiderman N, et al. Self-reported sleep disturbance is associated with lower CD 4 count and 24-h urinary dopamine levels in ethnic minority women living with HIV. Psychoneuroendocrinology. 2013;38(11):2647-53.

32. Robbins JL, Phillips KD, Dudgeon WD, Hand GA. Physiological and psychological correlates of sleep in HIV infection. Clinical Nursing Research. 2004;13(1):33-52. 
33. Borbély A, Wirz-Justice A. Sleep, sleep deprivation and depression. Hum Neurobiol. 1982;1(205):10.

34. Crum-Cianflone NF, Roediger MP, Moore DJ, Hale B, Weintrob A, Ganesan A, et al. Prevalence and factors associated with sleep disturbances among early-treated HIV-infected persons. Clin Infect Dis. 2012;54(10):1485-94.

35. Krystal AD. Psychiatric disorders and sleep. Neurol Clin. 2012;30(4):1389-413.

36. Reid S, Dwyer J. Insomnia in HIV infection: a systematic review of prevalence, correlates, and management. Psychosom Med. 2005;67(2):260-9.

37. Ailshire JA, Burgard SA. Family relationships and troubled sleep among US adults: examining the influences of contact frequency and relationship quality. J HealthSoc Behav. 2012;53(2):248-62.

38. Nokes KM, Kendrew J. Correlates of sleep quality in persons with HIV disease. J Assoc NursesAIDS Care. 2001;12(1):17-22.

\section{Figures}

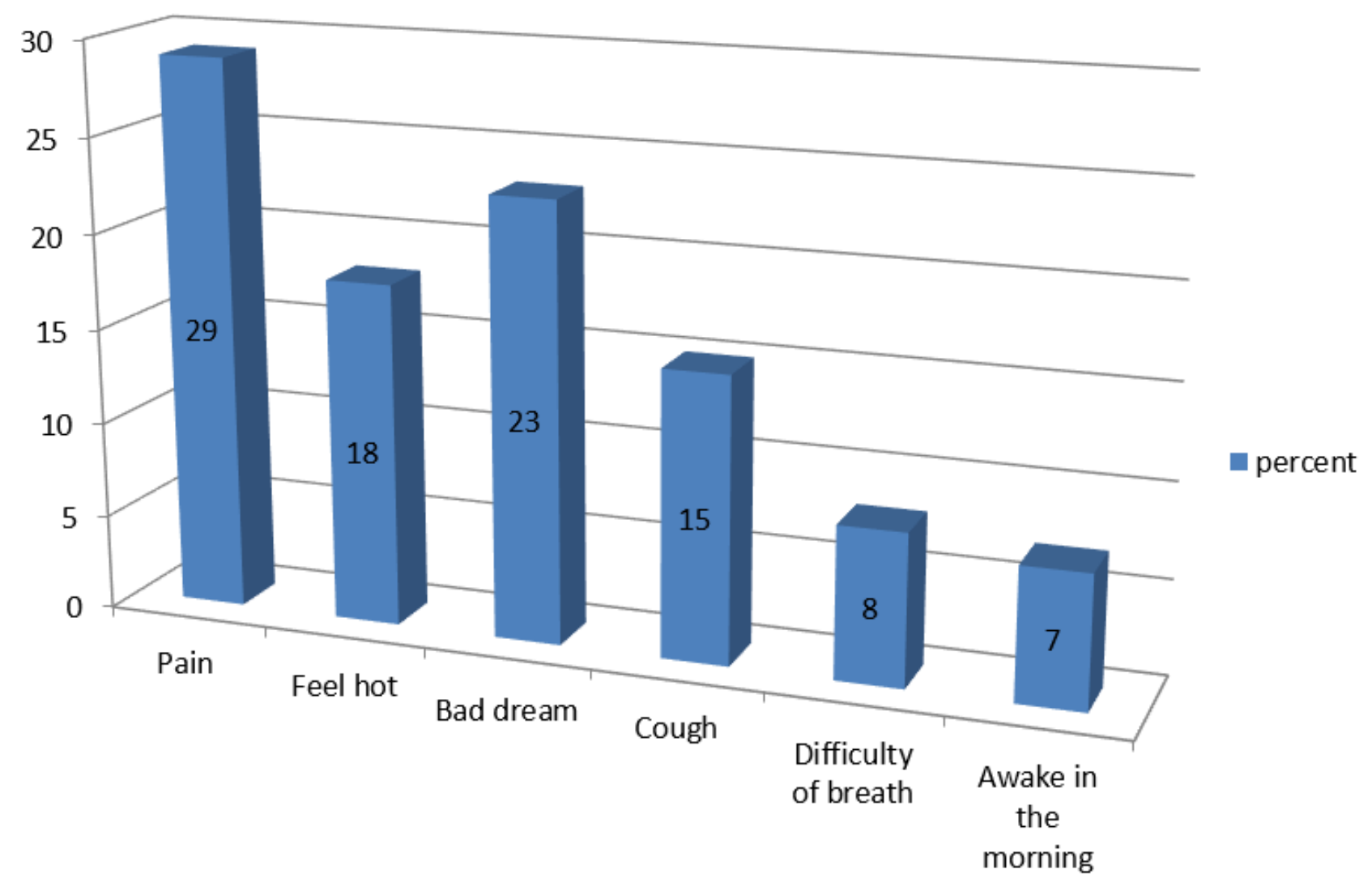

Figure 1 
The reasons for the difficulty of sleep among PLWHA at Dessie Referral Hospital, ART clinic Northeast 2019. 